\title{
Association between Rural Land Use Transition and Urban-Rural Integration Development: From 2009 to 2018 Based on County-Level Data in Shandong Province, China
}

\author{
Zhiheng Yang ${ }^{1}$, Nengneng Shen ${ }^{1}$, Yanbo $\mathrm{Qu}{ }^{2}$ and Bailin Zhang ${ }^{3, *}$ \\ 1 Institute of Regional Economics, Shandong University of Finance and Economics, Jinan 250014, China; \\ yzh2012@sdufe.edu.cn (Z.Y.); 192101030@mail.sdufe.edu.cn (N.S.) \\ 2 School of Public Management, Shandong University of Finance and Economics, Jinan 250014, China; \\ qyb20126008@sdufe.edu.cn \\ 3 School of Environmental Science and Engineering, Tianjin Polytechnic University, Tianjin 300387, China \\ * Correspondence: zhangbailin@tiangong.edu.cn; Tel.: +86-1892-060-5795
}

Citation: Yang, Z.; Shen, N.; Qu, Y.; Zhang, B. Association between Rural Land Use Transition and

Urban-Rural Integration

Development: From 2009 to 2018 Based on County-Level Data in Shandong Province, China. Land 2021, 10, 1228. https://doi.org/10.3390/ land 10111228

Academic Editor: Fabrizio Battisti

Received: 23 September 2021

Accepted: 9 November 2021

Published: 11 November 2021

Publisher's Note: MDPI stays neutral with regard to jurisdictional claims in published maps and institutional affiliations.

Copyright: () 2021 by the authors. Licensee MDPI, Basel, Switzerland. This article is an open access article distributed under the terms and conditions of the Creative Commons Attribution (CC BY) license (https:// creativecommons.org/licenses/by/ $4.0 /)$.

\begin{abstract}
Integrated development in urban and rural areas has led to a new form of urban-rural interdependence, which promotes rural territorial functional evolution and land use changes. Rural land use transition, showing the synchronous development between cities and villages, is an important window through which to observe integrated development in urban and rural areas. We focus on uncovering the association between rural land use transition and urban-rural integration development (URID), put forward a dynamic relationship assumption between rural land use transformation and URID stages based on the transmission mechanism of urban-rural linkages, and undertake empirical analysis using the panel regression model with the data of county-level administrative units in Shandong Province, China. The results show that rural land use transition has maintained a close association with URID, and that the changes in cultivated land, forest land, and surface-water area are highly related to URID. There are different leading urban-rural linkages in rural areas around big-sized cities, mid-sized cities, and small-sized cities, which determine whether rural areas are in different URID stages of high, medium, or low levels. Further, rural areas can take different actions to promote URID at different stages through strengthening or introducing urban-rural linkages driven by economies of scale and deepening urbanization. This provides a reference for developing countries to formulate rural land use policies on achieving the goal of URID.
\end{abstract}

Keywords: rural land use transition; urban-rural integration development (URID); dynamic relationship model; Shandong province; China

\section{Introduction}

Land use and cover change are the projection of regional socio-economic activities in space, which implies the interaction between land resources and wider aspects of development [1]. In recent years, industrialization and rapid urbanization have made great impacts on rural areas, leading to rural land use transition [2,3]. On the one hand, the dramatic increase in urban construction land leads to the massive loss of arable land, mainly characterized by urban sprawl and rural shrinkage [4]; on the other hand, with the changing of urban spatial structure and industrial designs, the functional position of rural areas is becoming more pluralistic. It includes not only the agricultural production, but also reflects the market returns or policy support that rural areas can obtain from food safety, minimum living standard security, landscape value, environmental protection, etc. [5-8]. Multi-functional evolution will inevitably lead to changes in rural land use patterns, layout, and scale directly, namely, rural land use transition. Rural land use transition is not only the result of urban function dispersal, but also the process of giving full play to rural comparative advantages and stimulating their own vitality. It represents the formation of 
the mechanism of promoting harmonized development between urban and rural areas, which is urban-rural integration development (URID).

As one of the ways to deal with the relationship between urban and rural areas, URID emphasizes the role of cities in driving rural development to promote rural revitalization, covering the coordinated development of urban and rural economy, society, ecology, and other dimensions [9]. At present, the common prosperity of urban and rural areas has become the consensus of universal development [10-12]. URID is the leading idea in the treatment of urban-rural relations. In 2018, The Office of Rural Work Leading Group of China Central Communist Party proposed the 'National Rural Revitalization strategic plan (2018-2022)', which clearly stated that rural revitalization should take the road of URID and build a mechanism for the full flow of urban and rural elements. Previous studies have indicated that these land change processes are often triggered by national and sub-national policies involving urban and rural development $[13,14]$. Under the incentive of URID policies, rural land use transition shows the synchronous development of urban and rural areas, which is an important window through which to observe URID.

A large number of studies have shown that land use transformation is closely related to urban and rural development. Long et al. [15] proposed a new policy of 'Urban-rural Integrated Reform' by analyzing Chongqing's land-use change and its policy driving forces from 1995 to 2006. Li [16] proved that there is a strong connection between land resource flows and that urban-rural interaction patterns change within the context of enlarged urban-rural inequalities. Serra et al. [17] noted that land-use intensification linked to human activity has changed considerably causing important modifications in the traditional dichotomized urban-rural relationships. Land use transformation affects the integration of multiple dimensions of urban and rural economy, society, and ecology, such as rural population and employment [18], regional economic growth [19], rural industrial structure adjustment [20], construction of public health facilities [21], and environment degeneration [22]. These studies demonstrated that land use transformation plays a vital role in the process of urban-rural transformation. For example, through theoretical analysis and empirical study of the Bohai Rim region, Li et al. [23] found strong connections between the land conversion rates and urban-rural transformation intensity in the period 2000-2010. Chen et al. [24] further analyzed the relationship between land use transitions and urbanrural integrated development by the econometric models based on China's provincial panel data from 2005 to 2016, and put forward that the current land use transitions have a negative impact on URID. Under ideal channels, it is supposed to promote urban-rural integrated development through an income effect, resource effect, and urbanization effect. This provides a research framework for the analysis of the correlation mechanism between rural land use transition and URID.

However, existing research pays more attention to the influence of the transformation of rural land into city construction land, and considers less the indicative role of rural land internal conversion in URID, as well as the mechanisms behind it. Few studies focus on the relationship between rural land use transformation and URID. Moreover, the existing research on the measurement of urban-rural integration development level mainly selects indicators from the perspective of the urban-rural development gap, e.g., urban-rural per capita income ratio or the urban-rural per capita consumption ratio [25,26], which does not reflect the cooperative ties between urban areas and rural areas based on agricultural and non-agricultural industry agglomeration. There is insufficient appreciation of the importance of URID anxo-action in the flow of urban-rural essential productive factors.

In China, after nearly 40 years of rapid urbanization development, rapid urbanization in the form of urban sprawl has slowed down. Under the background of urban renewal on the reuse of existing construction land, the situation of rural land conversion for urban development is changing gradually. The current discussion trend focuses on farmland converted from smallholders to large-scale agricultural production. Models from 'land grabbing' to 'co-developing' are the different development strategies of rural land use in the special urbanization stages $[27,28]$. Qu et al. [29] proposed that rural land consoli- 
dation should conform to the rules of land use transition and establish a multi-objective oriented regional differentiation strategy system. Yin et al. [30] offered a microscopic perspective of exploring the formation and change in rural land use and actual functions driven by Informal Industrialization. Zou et al. [31] established a uniform classification and value evaluation system of land use functions for China's rural land use planning and management based on the widely recognized 'ecological-production-living' function in sustainable development. Rural land use transition has both internal and external momentum, providing conditions for accelerating URID.

We focus on exploring the association mechanism between rural land use transition and URID, select Shandong Province in northern China as the research area for empirical analysis, and explore the transformation process from the traditional urban-rural dual structure system to the urban-rural unitary structure system through rural land use transition, so as to answer two questions, 'Is there a relationship between rural land use transition and URID?' and 'How are the land use transitions associated with URID?' We provide a methodological contribution for quantitatively measuring the urban-rural integration development and the effect of rural land use transformation on URID and expose a theoretical methodological model in capturing the URID effects of rural land use transition. It is helpful to explore the roles of rural land transformation in optimizing urban and rural economic and social structure, underscore the planning of rural land use in achieving the goal of URID, and solve the problems of excessive urbanization, lagging urbanization, and rural recession in the process of urbanization in developing countries.

The structure is as follows: Section 2 analyzes the association mechanism between rural land use transition and URID based on urban-rural linkages. Section 3 introduces the study area, data sources, and research methods. Section 4 measures the stage performance of URID corresponding to different types of rural land use transition. Section 5 presents the basic characteristics of URID's process and policy enlightenment. Section 6 draws the conclusions and future prospects of the study.

\section{The Association Mechanism between Rural Land Use Transition and URID}

Rural areas are the main places of agricultural production and the hinterlands of cities. In general, rural areas consist of cultivated land, forest land, grassland, surfacewater area, rural residential land, and unutilized land. Different kinds of rural land use have different function performance, such as agricultural production, residential living, employment security, landscape value, cultural inheritance, and ecological protection. The multi-functional performance of the rural land is based on the division and cooperation of production between urban and rural areas, reflecting the mutually beneficial linkages in urban-rural economic and social fields. Most urban-rural linkages belong to agriculture and non-agricultural industry clusters, such as food supply, industrial and agricultural goods flow, and rural-urban labor migration [32,33]. Some studies also found that waning transportation and communication costs, technological change and economic restructuring, rising real incomes, and changing tastes for natural amenities will trigger new urbanrural linkages [11,34], such as social welfare accessibility [35] and ecological environment cooperation [36]. These change the situation of urban and rural opposition and forms the basis for URID; in accordance with the functions of cities having changed from production bases to control centers, urban agglomeration and regional integration constitute the regional cluster/network of complex rural-urban agglomerations [37-39]. Urban-rural linkages become more diversified and frequent, the dynamics of rural-urban linkages and transformations can unfold in a more complementary and reciprocally beneficial manner over the regional territory. These urban-rural linkages continue to affect the multi-functional evolution of rural areas, such as the pastoral complex integrating circular agriculture, creative agriculture, and agricultural experience, the sightseeing agricultural park dominated by leisure tourism, and the agricultural product production and marketing system operated by the whole agricultural industry chain [40], which is the reflection of URID in multiple dimensions. 
Urban and rural areas share the regional commodity market and factor-market from the perspective of dual structure theory, as they exist with each other and cannot be separated. URID regards cities and villages as an organism, emphasizing the process of promoting production factors mobility and balancing the allocation of public resources [36,41]. Based on the conception of URID, the attempt to coordinate urban and rural areas breaks the inertia of traditional rural development. URID promotes urban-rural linkages in economic, social, ecological, and other fields through commodity circulation, population mobility, facility connectivity, public service provision, technology transmission, and environmental governance cooperation. In the early stage, urban-rural linkages are 'one-way', where labor, land, capital, and other production factors flow unidirectionally from rural areas to urban areas, reflecting the unequal status between urban and rural areas. In the late stage, rural areas are of great importance, urban-rural linkages display 'bilateral interaction', and the factors flow between urban and rural areas. The policies to enhance urban-rural linkages are viable for URID options. Strengthening original urban-rural linkages or implanting new urban-rural linkages has lead to rural land use transition. Rural land use transition and URID are in the same direction.

It can be seen that rural land use transition is an important manifestation of URID' $s$ process, which can capture the effect of the urban spread-backwash process on rural areas according to the existing spatial distribution of rural land, and witness the reshaping of the rural socio-economic structure and the optimization of the regional spatial pattern. The association mechanism between rural land use transition and URID is shown in Figure 1.

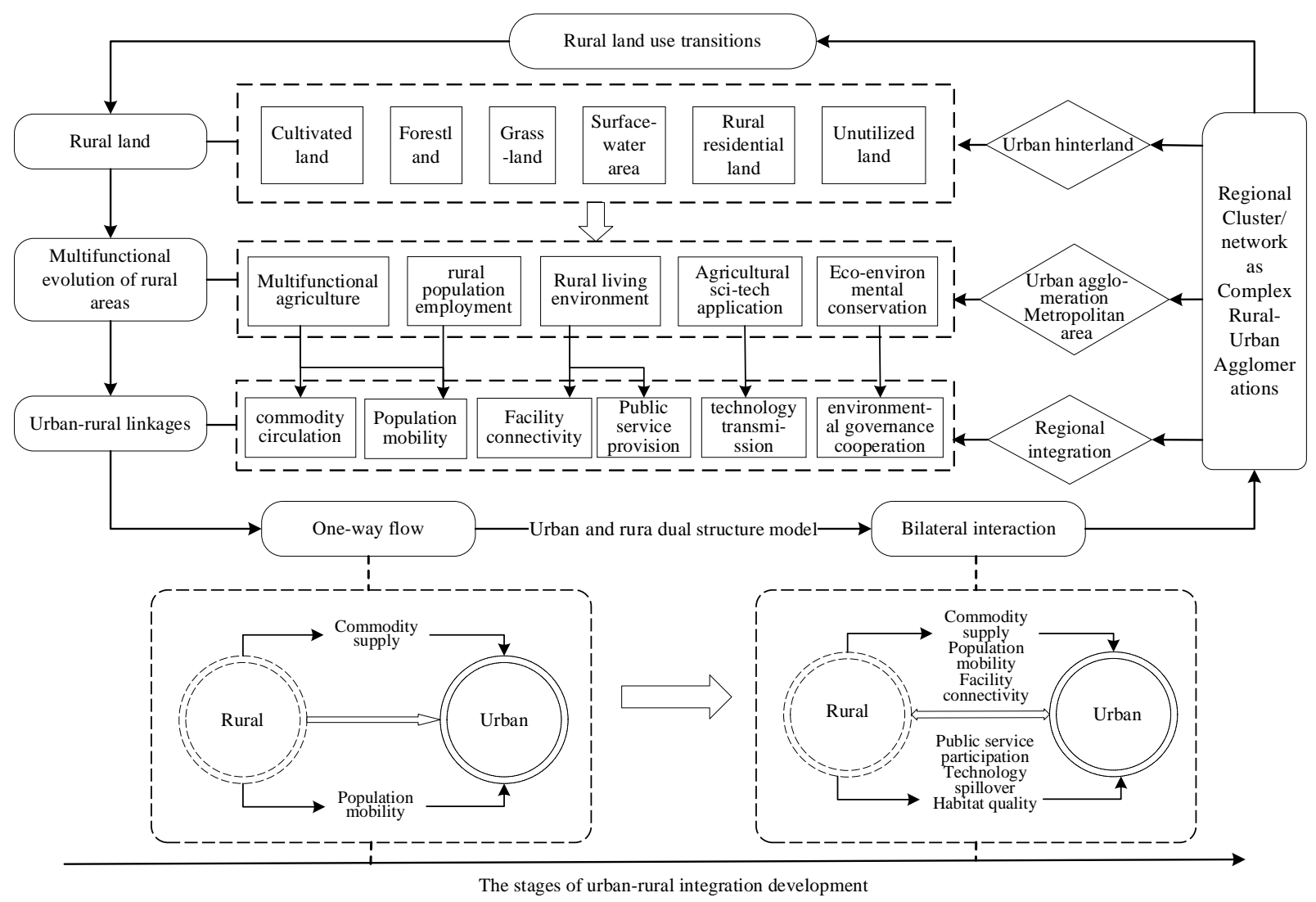

Figure 1. Association mechanism between rural land use transition and URID.

According to this, we propose the first assumptions:

Hypothesis 1 (H1). Rural land use transition is significantly associated with URID through urban-rural linkages. 
Rural land use transition shows the changes in rural tangible structures on physical space and social interaction, embodies urban-rural linkages established in the fields of industrial cooperation, market development, technology transmission, public goods, and service supply, and reflects URID determined by diversified urban-rural linkages. The change curve reflecting URID is a nonlinear and S-shaped growth curve, and the ascending trend meets Logistic growth parabola similar to the change curve of urbanization.

In practice, different rural areas differ in geographical location and resource endowment, which determine the different choices of urban-rural linkages. Therefore, rural land use transition shows different characteristics, corresponding to different URID stages (Figure 2).

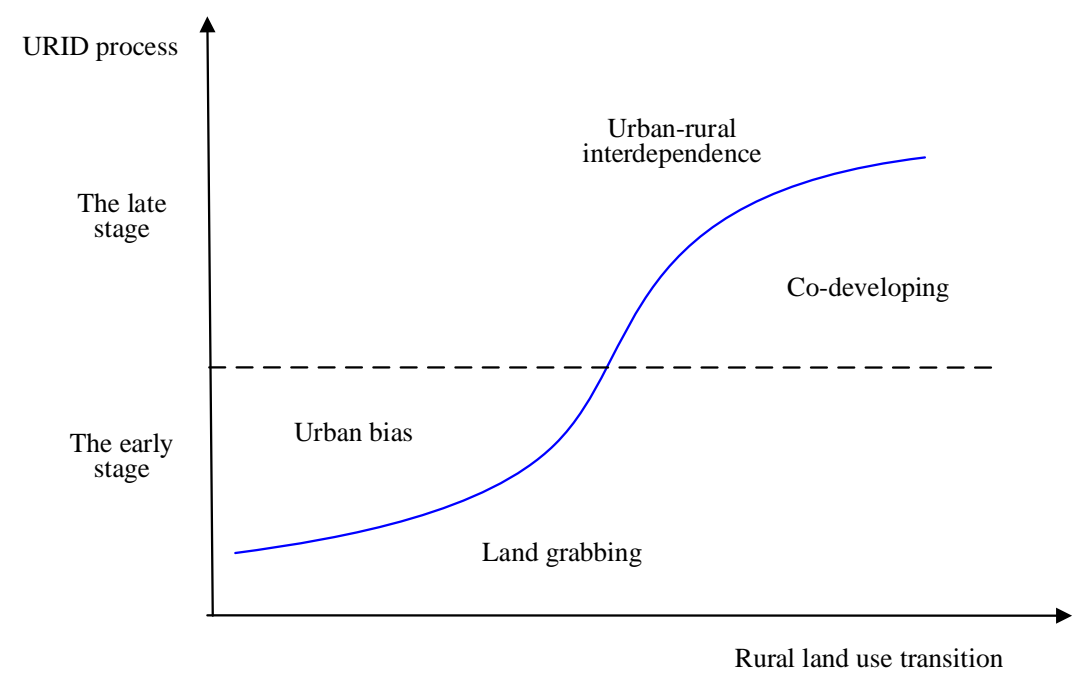

Figure 2. Dynamic process of rural land use transition and URID.

Therefore, we put forward the second hypothesis:

Hypothesis 2 (H2). The association between rural land use transition and URID presents dynamic changes.

Generally, for rural areas in the traditional farming state, rural land mainly undertakes the function of agricultural products production: there are few urban-rural linkages, the strength of urban-rural linkages is weak, production factors are dominated by one-way flows, and URID is in low level. For developed rural areas, the function of rural areas is constantly enriched along with urban development. Urban-rural linkages are diversified, frequent, and deepened. Production factors flow bidirectionally between urban and rural areas, and URID is in high level.

\section{Study Area, Data and Methods}

\subsection{Study Area}

Shandong Province is located on the northern coast of China, with convenient transportation and obvious location advantages (Figure 3). Shandong Province governs 16 prefecture-level cities and a total of 137 county-level administrative uints. There are approximately 100 million people in the region, and its land area accounts for $1.65 \%$ of the country. In 2018, Shandong's GDP accounted for $7.25 \%$ of the country's, of which the total agricultural output value reached 939.75 billion Yuan, ranking first in China. Shandong is one of the thirteen major grain-producing provinces in China, and agriculture is a basis for Shandong to maintain healthy economic and steady social development. From 2009 to 2018, the intensity of rural land use transition in Shandong Province increased, driven by industrialization and urbanization. The scale of rural construction land was increasing, and the area of rural residential land increased by $8.64 \%$. Meanwhile, the scale of 
agricultural land continued to decrease, and the cultivated land, forest land, grassland, and surface-water area were reduced by $1.16 \%, 3.94 \%, 8.49 \%$, and $1.76 \%$, respectively. The transition of rural land use characterized by internal structure adjustment was prominent. Rural land use transition and URID in Shandong Province are experiencing a high speed development phase. Up to now, 10 municipal districts and 5 counties and county-level cities have been set as the provincial urban-rural integration development pilot areas in Shandong Province, and Shandong Ji-Qing partial areas have been established as the national urban-rural integration development pilot areas, which provide rich materials for this study.

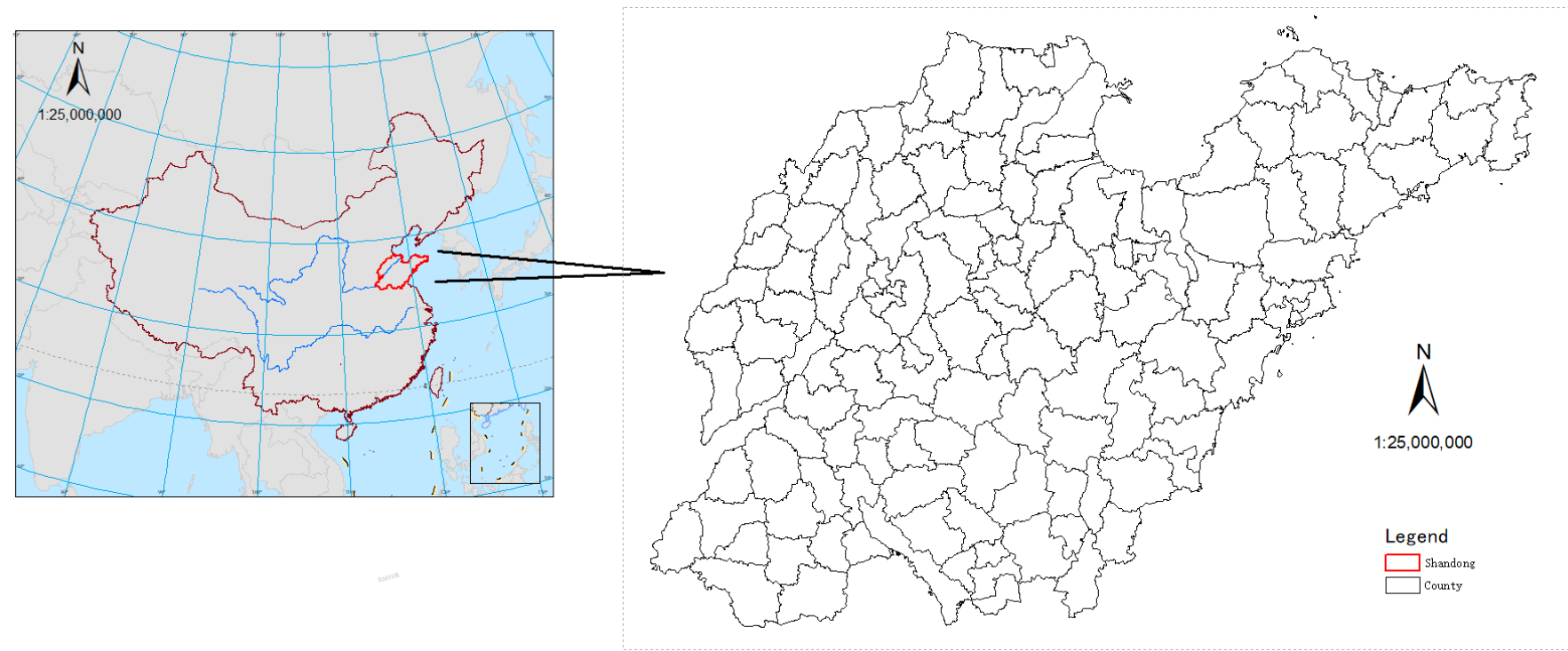

Figure 3. Location of the study area.

\subsection{Data Sources}

We select the county-level administrative units in Shandong Province as the research units, with a total number of 137 cases. The socio-economic data come from 'Shandong Statistical Yearbook,' 'China City Statistical Yearbook,' and 'Urbanization Development Report of Shandong Province' from 2010 to 2019; as well, some data come from social survey data-China Migrants Dynamic Survey (CMDS 2009-2018). Land use data come from the interpretation of remote sensing data from the Resource and Environment Science and Data Center of the Chinese Academy of Sciences (http:/ / www.resdc.cn, accessed on 23 September 2021). Referring to the national land classification criteria, the interpreted types of rural land use include cultivated land, forest land, grassland, surface-water area, rural residential land, and unutilized land. Since our research object is rural land use transformation, we divide the regional land into two categories, urban construction land and rural land, and only focus on the county-level administrative units with rural land. There were three county-level administrative units without rural land during 2009-2018, namely, Shinan municipal district, Shibei municipal district, and Sifang municipal district. All the land in these county-level administrative units is urban construction land. We eliminated these units in the evaluation to maintain the research consistency.

\subsection{Methods}

\subsubsection{Measurement of Rural Land Use Transition}

Land use transition is a manifestation of land use and land cover change (LUCC), and the land use morphology is the core of rural land use transition $[29,42]$. Therefore, we explore rural land use transition in view of the dominant morphology dimension of rural land use transition. Various indexes are used to describe the scale and structural changes in land use parcels, such as the area variable, proportion variable, and dynamic 
rate variable. Due to the fact that different types of rural land embody different land use functions, the corresponding bearing urban-rural linkages are also different. It is necessary to measure the change in each land type separately. Thus, we select the area and growth rate of cultivated land, forest land, grassland, surface-water area, rural residential land, and unutilized land as the measurement index. The calculation formula of the area growth rate per annum of various kinds of rural land is as follows:

$$
\Delta s_{i j t}=\frac{S_{i j t}-S_{i j t-1}}{S_{i j t-1}}
$$

where $S_{i j t}$ is the area of rural land $j$ in the county-level administrative unit $i$ in year $t$, and $\Delta s_{i j t}$ is the growth rate of $S_{i j t}$.

In order to facilitate the comparison of rural land use transition in different regions, we further measure the changes in rural land use in different regions. Firstly, according to the area of different kinds of rural land from 2009 to 2018, we calculate the average growth rate of rural land area in 10 years.

$$
\overline{\Delta s_{i j}}=\frac{\sum_{t=2010}^{2018} \Delta s_{i j t}}{9}
$$

where, $\overline{\Delta s_{i j}}$ is the average growth rate of rural land $j$ in the county-level administrative unit $i$.

Related to particular geographical location and natural resource endowment, the land use transformation of different rural areas is different, and urban-rural linkages are also different. Corresponding to this, the association performance of rural land use transition and URID is also different. In order to make a more comprehensive analysis of the association between rural land use transition and URID, the county-level administrative units are classified. Considering that the basis of URID is urban areas elevating rural areas, the central city adjacent to rural areas determines the performance of URID in this region. Referring to Li [16] and Berdegué et al. [43], rural areas are divided into three categories according to the scale of central cities which are surrounded by rural areas, Metropolitan rural areas around big cities (MRA), suburban rural areas close to moderate-sized cities (SRA), and remote rural areas close to small towns (RRA). The classification criteria are based on 'City scale division standard' (2014), issued by the State Council, China; that is, large cities with a population of more than 1 million people, moderate-sized cities with a population of 500,000 to 1 million people, and small cities with a population of less than 500,000 people. The classification of the county-level administrative units is shown in Figure 4.

Among them, RRA is mainly located in the periphery of small cities. Due to the small urban scale and limited market capacity, few types of urban-rural linkages are generated and the intensity of urban-rural linkages is low. There is insufficient impetus for urban driving of rural development, as well as a lack of motivation for URID. In contrast, SRA, often on the moderate-sized urban periphery, is similar to the urban ecological base and social culture. Inspired by urban expansion and rural polarization, urban-rural linkages are strengthened through optimizing the layout and structure of cities and towns, extending urban infrastructure to villages and improving the level of public services. Rural areas gradually break the traditional isolated situation, combine with the urban economy, and integrate into the regional unified development system. MRA is mainly located in metropolitan areas. The advantages of strong economic strength, large population, wide market, high disposable income, and convenient transportation have formed diversified urban-rural linkages. The close urban-rural linkages make it possible to achieve deep URID. 


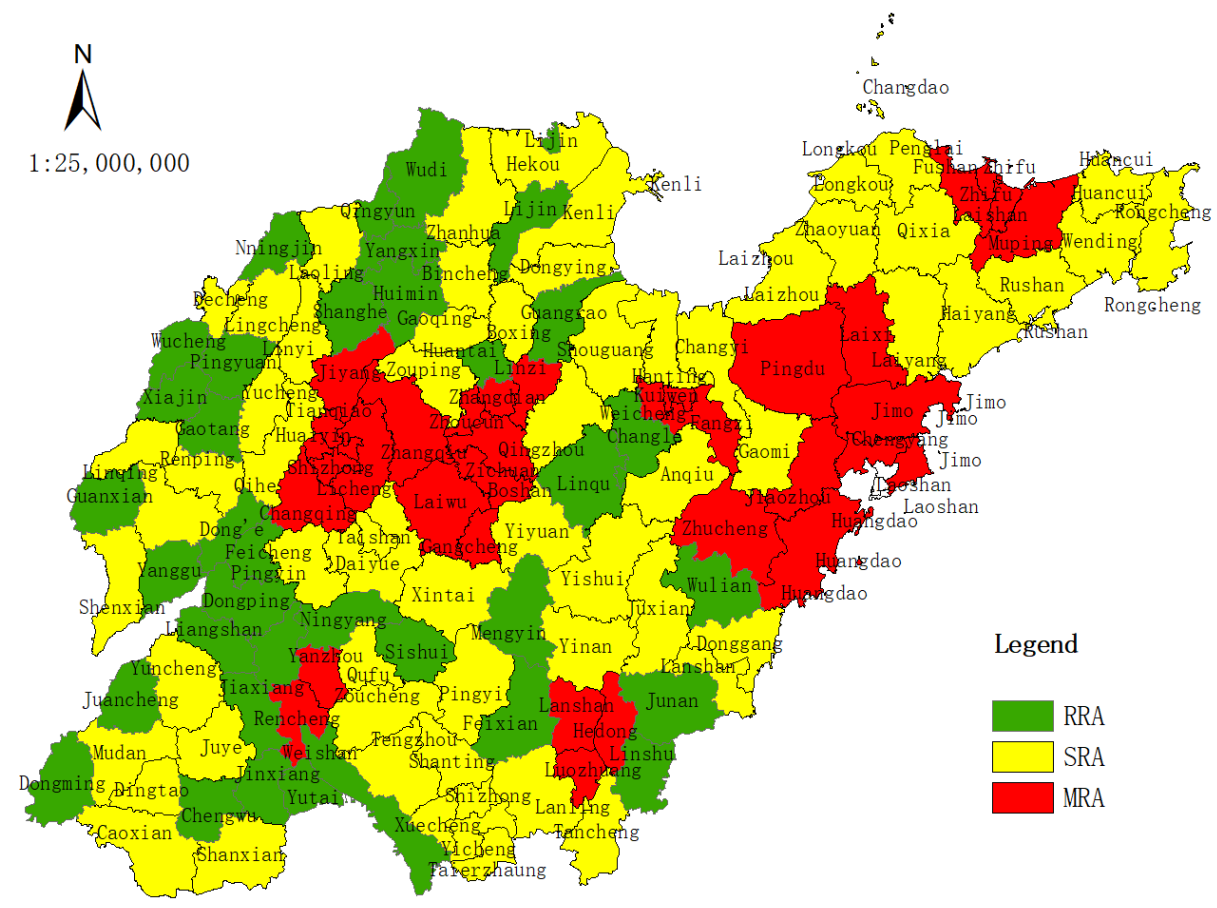

Figure 4. The distribution of different types of rural areas.

Then, according to the classification results of MRA, SRA, and RRA, the average growth rate per annum of $\overline{\Delta s_{i j}}$ is calculated to reflect rural land use transition in different regions.

$$
\begin{aligned}
& \mathrm{S}_{\text {MRA }}^{\mathrm{j}}=\frac{\sum_{i=1}^{k_{1}} \overline{\Delta S_{i j}}}{k_{1}} \\
& \mathrm{~S}_{\mathrm{SRA}}^{\mathrm{j}}=\frac{\sum_{i=1}^{k_{2}} \overline{\Delta S_{i j}}}{k_{2}} \\
& \mathrm{~S}_{\mathrm{RRA}}^{\mathrm{j}}=\frac{\sum_{i=1}^{k_{3}} \overline{\Delta S_{i j}}}{k_{3}}
\end{aligned}
$$

Among them, $k_{1}, k_{2}$, and $k_{3}$ are the number of the county-level administrative units contained in region MRA, SRA, and RRA; $\mathrm{S}_{\mathrm{MRA}}^{\mathrm{j}} \mathrm{S}_{\mathrm{SRA}}^{\mathrm{j}}$ and $\mathrm{S}_{\mathrm{RRA}}^{\mathrm{j}}$ are the average growth rate of rural land $j$ in region MRA, SRA, and RRA. The larger the value of $S_{\mathrm{MRA}^{\prime}}^{j} \mathrm{~S}_{\mathrm{SRA}}^{\mathrm{j}}$, and $\mathrm{S}_{\mathrm{RRA}}^{\mathrm{j}}$, the greater the rural land use transition.

\subsubsection{Evaluation of URID}

According to the mechanism analysis, it is believed that diversified urban-rural linkages provide more opportunities for production factors mobility and public resources allocation between urban and rural areas, which provide the basis for the evaluation of the association between rural land use transition and URID. The diversified urban-rural linkages, such as commodity circulation, population mobility, facility connectivity, public service provision, technology transmission, and environmental governance cooperation, are the manifestation of URID in economy, society, and ecology fields. URID constitutes the physical spatial connection and social support network between urban and rural areas, and changes with the different stages of urban and rural economic and social development. Thereafter, we construct an index system to measure the level of URID on the basis of urban-rural linkages. The process begins with sorting out the types of existing urban-rural linkages, and the URID evaluation index system is divided into six dimensions: commodity circulation, population mobility, facility connectivity, public service provision, technology transmission, and Environmental governance cooperation. The selection of indicators 
follows the principles of data availability, systematization, and representativeness, as shown in Table 1.

Table 1. Measurement index system of URID level.

\begin{tabular}{|c|c|c|}
\hline Dimension & Index & Calculation Method \\
\hline Commodity circulation & $\begin{array}{l}\text { Commercialization rate of agricultural } \\
\text { products }(\%)\end{array}$ & $\begin{array}{c}\text { [Total grain output-(Number of rural } \\
\text { population } \times \text { Annual per capita } \\
\text { consumption of grain)]/Total regional } \\
\text { grain output }\end{array}$ \\
\hline Population mobility & $\begin{array}{l}\text { Proportion of agricultural population in local } \\
\text { floating population }(\%)\end{array}$ & $\begin{array}{c}\text { Number of local rural population in } \\
\text { floating population/Total floating } \\
\text { population }\end{array}$ \\
\hline Facility connectivity & Road network density $\left(\mathrm{km} / \mathrm{km}^{2}\right)$ & Road mileage/Total regional area \\
\hline Public service provision & $\begin{array}{l}\text { Number of beds per capita in medical and } \\
\text { health institutions (PCs. } / 10,000 \text { persons) }\end{array}$ & $\begin{array}{l}\text { Number of beds in medical and health } \\
\text { institutions/Total regional population }\end{array}$ \\
\hline Technology transmission & $\begin{array}{l}\text { Agricultural mechanization level } \\
\qquad(10,000 \mathrm{~kW} / \mathrm{ha})\end{array}$ & $\begin{array}{l}\text { Total power of agricultural } \\
\text { machinery/Arable land area }\end{array}$ \\
\hline $\begin{array}{l}\text { Environmental governance } \\
\text { cooperation }\end{array}$ & Harmless disposal rate of domestic garbage $(\%)$ & $\begin{array}{c}\text { Harmless treatment capacity of domestic } \\
\text { garbage/Total domestic garbage }\end{array}$ \\
\hline
\end{tabular}

Commodity circulation, especially food supply, is one of the most important forms of urban-rural linkages. It embodies the vertical division system of urban and rural production. The neoclassical economics theory explains urban-rural linkages shown by the specialization of urban and rural production based on industrialization, which are increasing with the opening of urban and rural markets and the extension of the agricultural production chain [44]. With the increase in agricultural product income, the rural household expenditures for non-agricultural goods and services is also rising. This forms a virtuous circle of URID. The commercialization rate of agricultural products is selected as a representative indicator, reflecting agricultural products' supply capacity and organizational level of rural integration into urban economic system. This ensures not only stable economic conditions but also a degree of convergence between urban and rural areas, which allows URID to function smoothly.

Population mobility is the choice of the rural population to move between urban and rural areas in order to obtain employment opportunities and increase income. According to the Population and Housing Census, it is difficult for the rural population to solely depend on primary land activities for their sustenance. The main form of population mobility is the migration of the rural population to cities, driven by the reduction in agriculture labor demand and the income expectation of cities. Population mobility is also a common form of urban-rural linkage and provides a viewing angle to observe URID from the perspective of micro production units such as families and enterprises [45]. We chose the proportion of agricultural population in local floating population as a representative indicator, which represents the status on the demand and supply of labor marketing and effectively reflects the level of urban and rural population mobility.

Facility connectivity refers to various infrastructure facilities equipped in rural areas, including roads, bridges, transit, water systems, the electric grid, and communications networks, which build the bridges for personnel and material exchange. Facility connectivity is the physical guarantee for URID. Modern transportation, communication, and information technology conditions have brought about the space-time compression effect of geographical space, changed the flow mode of urban and rural population and goods, reduced transportation costs, improved circulation efficiency, and brought opportunities for remote villages [46]. The Road network density is chosen as the representative indicator. A higher value indicates a higher level of URID.

Public service provision refers to the availability of public goods and services. Due to the vast territory of rural communities and the low degree of residents' settlement, rural public service construction faces a dilemma between efficiency and fairness. The common 
measures are to promote the extension of urban public service facilities to remote rural areas, increase the service radius of public service facilities, and improve the public service level of rural communities [35]. We select the number of beds per capita in medical and health institutions as a representative indicator. It reflects the degree of equalization of urban and rural public services, which is also a positive indicator.

Technology transmission refers to the level of agricultural modernization under the influence of urban-rural technical linkages. Technology has advanced through urban and rural co-evolution and sustainable development. As the headstream of technological innovation, cities arouse agricultural modernization by aiding urban technology "spillovers", innovation and knowledge transfer, and accelerating the progress of agricultural mechanization, agricultural informatization, and agricultural organization innovation so as to improve the efficiency of agricultural production and the industrial integration between urban and rural areas. It is an inevitable choice to take the road of urban-rural integration development. Considering the availability of data, we selected the level of agricultural mechanization as the representative indicator, representing the degree of agricultural modernization. The higher the value is, the higher the level of URID is.

Environmental governance cooperation refers to the improvement of urban and rural living environment and the improvement of life quality, which benefits from the cooperative governance of urban and rural ecological environment. Urban and rural areas are contiguous in geographical space and belong to the same ecosystem, and must cooperate closely in pollution control, resource recovery, and quantitative reduction, as well as ecological diversity and the protection of open space. This can ensure the stability and health of the regional ecosystem and cooperatively control the hazard of ecological environment $[36,47]$. The harmless disposal of domestic garbage is selected as the representative index. According to the national plan for the construction of harmless treatment facilities for urban domestic garbage in the thirteenth five-year plan, the system of classified delivery, classified collection, classified transportation, and classified treatment of domestic garbage was built in urban and rural areas. This indicator represents the coordinated action of urban and rural areas in protecting the ecological environment. The higher the value is, the higher the level of URID is.

As a whole, various urban-rural linkages are intertwined, constituting the material connection and social support network between urban and rural areas, and changing with the different stages of urban and rural economic and social development. It not only inspires reflection on the existing development path, but also provides clues for grasping the future development trend of URID. To calculate the URID indexes, firstly, the analytic hierarchy process is used for weight distribution, then the entropy method is chosen to determine the weights of the various indicators of the index layer, and, finally, a linear weighted sum method is used to calculate the URID indexes of the county-level administrative units from 2009 to 2018.

\subsubsection{Variables and Models}

Based on the association mechanism analysis, the theoretical model of the association between rural land use transition and URID is established. Rural land use transition is taken as the independent variable, and URID index is taken as the dependent variable. In order to avoid missing variables and to comprehensively consider the economic and social driving factors that determine URID, we introduce GDP, financial revenue, and urbanization rate as the control variables. In general, the higher the level of economic development, the more prosperous the city is, therefore the urban spillover effect of agglomeration economies is more significant, and the leading role of the central city for rural development is obvious. Such areas have extensive urban-rural linkages and a high level of URID. Similarly, financial revenue is also one of the key indicators of regional development. Financial revenue reflects the government's ability to redistribute resources, especially to assess the welfare cost of raising a marginal unit of tax revenue in a balancedbudget. This is important for balancing the gap between urban-rural development on 
providing public goods and services to meet social needs. Usually, urbanization rate is calculated by the proportion of urban permanent population in the total population, aiding the investigation of the scale and distribution of urban growth. The urbanization rate index can control the net effect of urbanization on the transformation from agricultural land to construction land, and more accurately measure the association between rural land use internal transition and urban-rural integration development, ignoring the deviation in the research results caused by urbanization.

The model settings are as follows:

$$
\begin{gathered}
F_{i t}=\partial_{0}+\partial_{1} \text { cultivated }+\partial_{2} \text { forest }+\partial_{3} \text { grassland }+\partial_{4} \text { water }+\partial_{5} \text { residential }+\partial_{6} \text { unutilized }+\beta_{1} g d p \\
+\beta_{2} \text { revenue }+\beta_{3} \text { urbanization }+\mu_{i}+\gamma_{t}+\varepsilon_{i t}
\end{gathered}
$$

where $i$ and $t$ represent the county-level administrative unit and the year, respectively. Cultivated, forest, grassland, water, residential, and unutilized are the logarithms of cultivated land, forest land, grassland, surface-water area, rural residential land, and unutilized land, respectively. Gdp, revenue, and urbanization are the logarithms of GDP, public budget revenue, and urbanization rate. $F_{i t}$ represents the URID index of place $i$ in year $t . \partial_{i}$ and $\beta_{i}$ are the coefficients to be estimated, $\mu_{i}$ is individual-special effect, $\gamma_{t}$ is time-special effect, and $\varepsilon_{i t}$ is random error term.

\section{Results Analysis}

\subsection{Correlation Analysis of Rural Land Use Transition and URID}

After the log transformation of the data, panel regression analysis was carried out to judge the association between rural land use transition and URID from 2009 to 2018. A fixed effect model was selected according the results of the Hausman test. The F test result of the model is Prob $>$ F $=0.0000$, indicating that rural land use transition is significantly associated with URID. The regression results are shown in Table 2.

\begin{tabular}{|c|c|}
\hline Variable & URID Index \\
\hline \multicolumn{2}{|l|}{ Independent variable } \\
\hline Cultivated land transition & $\begin{array}{c}0.745^{* * *} \\
(2.67)\end{array}$ \\
\hline Forest land transition & $\begin{array}{c}-0.571^{* * *} \\
(-3.73)\end{array}$ \\
\hline Grassland transition & $\begin{array}{l}0.017 \\
(0.39)\end{array}$ \\
\hline Surface-water area transition & $\begin{array}{c}-0.467 * * * \\
(-3.34)\end{array}$ \\
\hline Rural residential land transition & $\begin{array}{c}-0.574^{*} \\
(-1.77)\end{array}$ \\
\hline Unutilized land transition & $\begin{array}{c}0.405^{* *} \\
(2.25)\end{array}$ \\
\hline \multicolumn{2}{|l|}{ Control variable } \\
\hline GDP & $\begin{array}{c}0.078 * * \\
(2.01)\end{array}$ \\
\hline Public budget revenue & $\begin{array}{l}0.015 \\
(1.28)\end{array}$ \\
\hline Population urbanization rate & $\begin{array}{c}0.043^{* *} \\
(2.52)\end{array}$ \\
\hline Constant & $\begin{array}{l}0.313 \\
(0.20)\end{array}$ \\
\hline Observations & 1370 \\
\hline R-squared & 0.352 \\
\hline County FE & YES \\
\hline Year FE & YES \\
\hline
\end{tabular}

Table 2. Regression results.

Regression coefficient results show that the transitions of cultivated land, forest land, and surface-water area are closely related to URID. The transitions of unutilized land 
and rural residential land are related to URID. The coefficient of grassland transition is small and not significant. It shows the difference in rural land use performance bearing urban-rural linkages.

Cultivated land transition was highly correlative with URID index during the study period, and the coefficient is positive. As a general term for land types such as dry farming cropland, vegetable fields, fruit-garden, orchards, groves, and nurseries, cultivated land produces grain and agricultural products such as vegetables, fruits, meat, and eggs. It embodies a variety of urban-rural linkages represented by food supply, population mobility, technology transmission, and facility connectivity. The change in the amount of cultivated land affects the production of agricultural products supplied to cities and non-farm payroll employment. Meanwhile, the growing demand for agricultural products promotes cropping structure adjustment in rural areas and affects cultivated land transition. It shows that agricultural production, as the fundamental function of rural areas, constitutes the cornerstone of URID in rural areas.

Forest land transition and surface-water area transition are negatively correlated with URID index and are significant at the level of $1 \%$. The utilization of forest land and surface-water area leads rural multifunction and landscape reformulation and enhances the service-oriented urban-rural linkages, such as rural experience tourism, amusement and leisure, and historical experience. On the other hand, forest land and surface-water area undertake the function of maintaining the integrity of the ecosystem and influence the ecological service functions. These land transitions are related to the regional habitat quality as well as urban areas, and determine the level of URID in the ecological field.

Rural residential land transition has a negative correlation with URID and is significant at the level of $10 \%$. As the space for rural population living and production, rural residential land is represents a human survival material foundation and production material. The scale and spatial distribution of rural residential land comprehensively shows the service scope of industry, employment, farming radius, transportation network, and public facilities under the framework of urban-rural cooperation. It reflects the diversified urban-rural linkages, such as commodity circulation, population mobility, public service provision, and facility connectivity. At present, under the guidance of rural construction policies, a large number of scattered rural settlements have been transformed into new rural communities through the renovation of hollow villages, the construction of central villages, and the migration of central towns. The number of rural settlements has been continuously reduced; however, there is a phenomenon of 'building new houses without demolishing old houses', which brought the question of idle rural residential land (IRRL). This phenomenon represents the low efficiency of land resource utilization, which is unfavourable for the protection of ecological environment and local rural culture, and deviates from the goal of URID.

There is a significant positive correlation between unutilized land transition and URID index. Unutilized land includes the low beaches, salinealkali land, weeds land, bare land, etc. As the cultivated land reserves resources, the exploitation of unutilized land is encouraged to develop leisure agriculture and rural tourism, and impels the ecosystem services value to increase with the transformation from unutilized land to forestland and field. Under the strict policy of cultivated land protection, it is also required to make full use of the unutilized land resources for urban and rural construction, and to occupy as little or no farmland as possible. Therefore, unutilized land indirectly embodies the urban-rural linkages of commodity circulation and facility connectivity, and relates to the rebuilding of regional habitat quality. In case of the scarcity of cultivated land reserve resources in Shandong Province, unutilized land plays a great role in balancing the demand of urban and rural construction land and has a great impact on URID.

Grassland transition is not significantly correlated with URID index. Grassland is mainly used for livestock production. Meanwhile, grassland has high ecological sensitivity, and, therefore, it embodies the urban-rural linkages of commodity circulation and environmental governance cooperation. Shandong Province is the major grain producing region in 
China, with only a few natural grasslands scattered in spatial distribution. This determines that grassland transition has no relevance to URID index in the study area.

In brief, the transformation of various types of rural land is closely related to URID index, and is aided by diversified urban-rural linkages. The results verify the research hypothesis that ' $\mathrm{H} 1$ : Rural land use transition is significantly associated with URID through urban-rural linkages.'

\subsection{The Stage Performance of URID Corresponding to Rural Land Use Transition}

We calculated the comprehensive indexes and sub-dimensional indexes representing the URID of three kinds of rural areas from 2009 to 2018, shown in Figure 5. This provides a basis for further evaluation of the association between rural land use transition and URID.

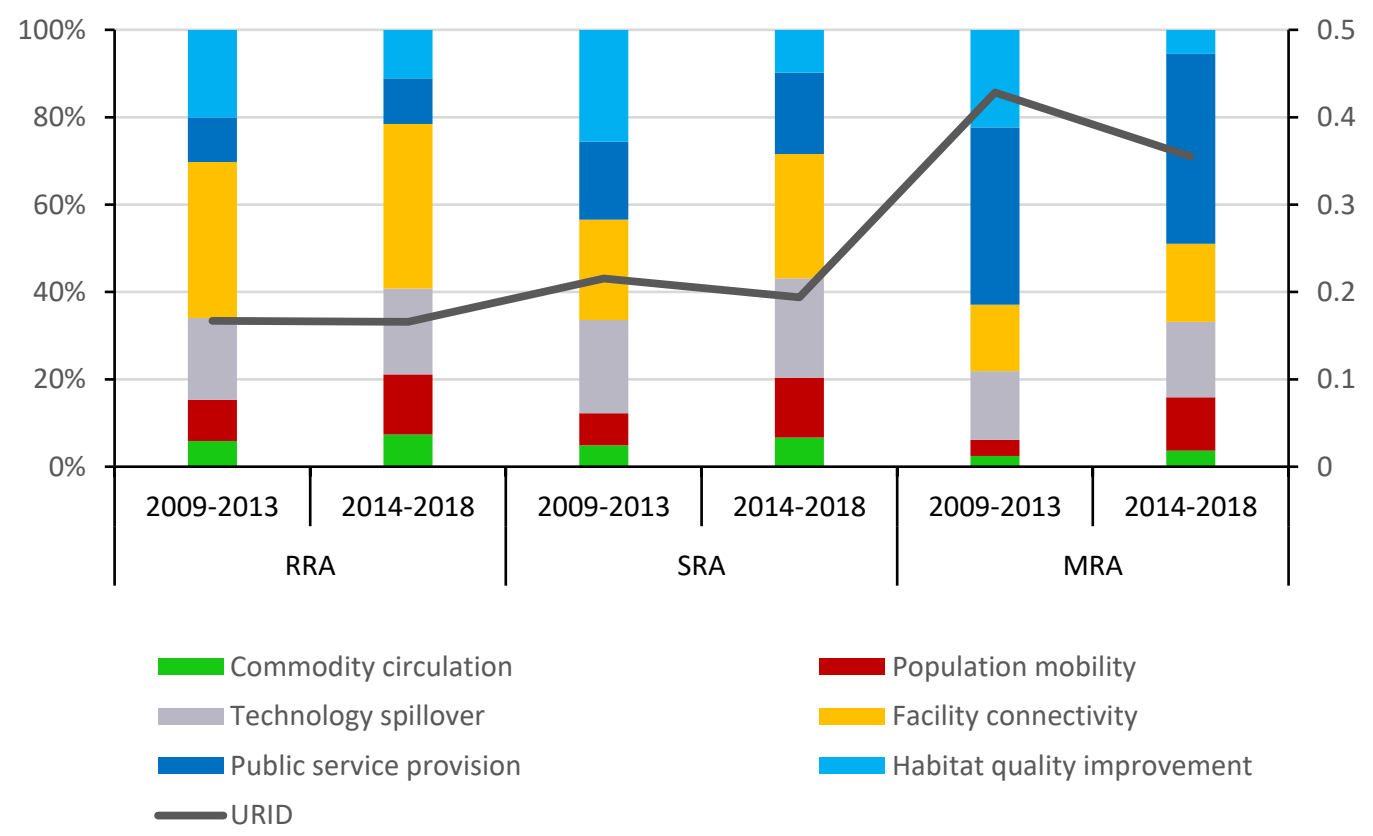

Figure 5. URID index and sub-dimensional index of three types of rural areas from 2009 to 2018.

Regression analysis is conducted to determine the association performance of rural land use transition and URID based on the data of RRA, SRA, and MRA. The model passes the test of significance and offers an effective way to explore the correlation of land use transitions of different types of rural areas and URID index. The specific regression results are shown in Table 3.

Table 3. Summary of regression results.

\begin{tabular}{lccc}
\hline \multicolumn{1}{c}{ Variable } & RRA & SRA & MRA \\
\hline Independent variable & & & \\
\hline Cultivated land transition & -0.323 & $0.803^{* * *}$ & $0.760^{*}$ \\
Forest land transition & $(-0.59)$ & -2.06 & -1.81 \\
& 0.155 & $-0.660^{* * *}$ & -0.14 \\
Grassland transition & -0.34 & $(-3.96)$ & $(-0.39)$ \\
& -0.047 & 0.083 & 0.006 \\
Surface-water area transition & $(-0.77)$ & -1.43 & -0.04 \\
& -0.089 & $-0.603 * * *$ & -0.325 \\
Rural residential land transition & $(-0.35)$ & $(-3.16)$ & $-1.22)$ \\
& 0.182 & -0.297 & -0.976 \\
Unutilized land transition & -0.39 & $(-0.76)$ & 0.435 \\
& -0.034 & $0.356 * *$ & -0.81 \\
\hline
\end{tabular}


Table 3. Cont.

\begin{tabular}{lccc}
\hline \multicolumn{1}{c}{ Variable } & RRA & SRA & MRA \\
\hline Control variable & & & \\
\hline GDP & 0.024 & $0.080^{*}$ & 0.109 \\
Public budget revenue & -0.28 & -1.8 & -1.13 \\
& 0.05 & 0.01 & 0.037 \\
Population urbanization rate & -1.48 & -1.29 & -0.59 \\
& $0.042^{* *}$ & 0.028 & $0.044^{*}$ \\
Constant & -2.27 & -1.07 & -1.71 \\
Observations & 3.453 & -1.705 & 0.577 \\
R-squared & -1.23 & $(-0.65)$ & -0.15 \\
County FE & 360 & 630 & 380 \\
Year FE & 0.372 & 0.295 & 0.661 \\
\hline Note & YES & YES & YES \\
\hline
\end{tabular}

Note: ${ }^{*}, * *, * *$ represent $10 \%, 5 \%, 1 \%$ significance levels, respectively; $t$ values in parentheses.

Table 4 reports the association coefficient of RRA, SRA, and MRA land use transition and URID index. Combined with the sub-dimension indexes of URID, we analyze the changes in urban-rural linkages leading to land use transformation in different types of rural areas and judge the corresponding relationship between land use transitions of different types of rural areas and URID stages.

Table 4. Corresponding relationship between rural land use transition and URID.

\begin{tabular}{|c|c|c|c|c|c|}
\hline \multirow{2}{*}{ Classification } & \multicolumn{2}{|c|}{ Rural Land Use Transition } & \multirow{2}{*}{$\begin{array}{l}\text { Dominant Urban-Rural } \\
\text { Linkages }\end{array}$} & \multirow{2}{*}{ Correlation } & \multirow{2}{*}{ the Stage of URID } \\
\hline & Specific Land Types & Range of Change & & & \\
\hline RRA & $\begin{array}{l}\text { Cultivated land } \downarrow \text {, Forest land } \downarrow \text {, } \\
\text { Grassland } \downarrow \text {, Surface-water area } \downarrow \text {, Rural } \\
\text { residential land } \uparrow \text {, Unutilized land } \\
\text { remains unchanged }\end{array}$ & $\begin{array}{l}\text { with a wide range of } \\
\text { variations. }\end{array}$ & Facility connectivity & Uncorrelated & low level \\
\hline SRA & $\begin{array}{l}\text { Cultivated land } \downarrow \text {, Forest land } \downarrow \text {, } \\
\text { Grassland } \downarrow \text {, Surface-water area } \downarrow \text {, Rural } \\
\text { residential land } \uparrow \text {, Unutilized land } \downarrow\end{array}$ & $\begin{array}{l}\text { with a narrow range } \\
\text { of variations. }\end{array}$ & $\begin{array}{l}\text { Facility connectivity, } \\
\text { Technology transmission }\end{array}$ & Strongly & Moderate level \\
\hline MRA & $\begin{array}{l}\text { Cultivated land } \uparrow \text {, Forest land } \downarrow \text {, } \\
\text { Grassland } \downarrow \text {, Surface-water area } \downarrow \text {, Rural } \\
\text { residential land } \uparrow \text {, Unutilized land } \downarrow\end{array}$ & $\begin{array}{l}\text { with a narrow range } \\
\text { of variations. }\end{array}$ & $\begin{array}{l}\text { Public service prvision, } \\
\text { Facility connectivity, } \\
\text { Technology transmission, } \\
\text { Environmental governance } \\
\text { cooperation }\end{array}$ & Weakly & High level \\
\hline
\end{tabular}

The above results show that the land use transitions in RRA, SRA, and MRA have different characteristics, with different leading urban-rural linkages and corresponding stages of URID.

\subsubsection{RRA}

From 2009 to 2018, rural land use transformation of RRA is the most intense, reflected in the rapid reduction of cultivated land, forest land, and grassland, and the rapid growth of rural residential land. All kinds of rural land vary within wide limits. The average URID index score is 0.1665 . This means that RRA belongs to the stage of low-level URID. Similar results are found in Li et al.'s [23] study, 'Rapid land conversion normally takes place in counties/districts of low initial level of urban-rural transformation'. The study shows that these areas are still in the stage of separation from cities, and are less affected by urban employment and entrepreneurial opportunities, personal consumer services, and public services, which makes little or no progress in achieving the goal of URID in RRA.

The empirical results show that URID in RRA is not so optimistic in terms of the URID sub-dimension indexes from 1978 to 2008, the scores are low and urban-rural linkages are loose. The most important urban-rural linkage leading URID in RRA is facility connectivity, which indicates that physical connectivity is the primary condition for URID. The following leading urban-rural linkages are technology transmission, environmental 
governance cooperation, and population mobility, implying the traditional foundation and natural base of rural areas provide the original driving force for urban-rural linkages. Commodity circulation is the most ubiquitous urban-rural linkage, and it accounts for the smallest proportion of all linkages because agriculture production is insignificant in urban economic decision-making; the support for promoting URID is limited.

The regression results also show that the correlation between rural land use transition and URID in this region is not significant; the changes in rural land are not interfered with URID. The coefficients of various types of rural land use transitions and URID are opposite to those of other types of rural areas. This means that URID has not yet been formed in RRA, rural areas are more plundered by urban expansion, and cities have made little achievement towards driving rural development. The strategy of promoting URID in RRA should first improve the level of urbanization, complete the process of 'drawing agricultural surplus to finish the accumulation of industry', and accumulate capitals, training personnel, and the latest information for integrated development.

\subsubsection{SRA}

In the process of rural land use transformation of SRA, the downtrend of cultivated land, forest land, and grassland still remains; however, the reduction rate is slower than that of RRA. The reduction rates of surface-water and unutilized land are accelerated, and the growth rate of rural residential land is slowly increasing. The average score of the URID index in SRA is 0.2047, and SRA is in the stage of middle-level URID, indicating that the relationship between urban and rural areas has changed from isolate effect to peer effect. There is an orderly transfer of factors around industrial growth and social interaction, which forms an internal driving force for promoting URID.

URID sub-dimensional indexes show that urban-rural linkages in SRA are close-knit and mutually complementary, the dominant urban-rural linkages are facility connectivity and technology transmission. The respective percentage of these two dimensions in SRA are lower than those in RRA, and the proportion of public service provision has increased. This shows that, in addition to the benefits of cooperation in the economic field, the pursuit of fairness in the social field is also an important component of URID.

The results of the regression model test indicate that rural land use transition in SRA is closely related to URID. The regression coefficients of cultivated land transition and unutilized land transition are significantly positive, while forest land transition, surfacewater area transition, and rural residential land transition are significantly negative. The status of urban-rural governance segmentation has been broken, which has intensified social mobility. This is conducive to promoting urban quality improvement and rural revitalization at the same time. The implantation of new urban-rural linkages in SRA has shifted from spontaneous to organized. The region has carried out systematic actions in terms of ideas, planning, policies, and regulations to promote URID.

\subsubsection{MRA}

Rural land use transition in MRA has narrow variations; among them, cultivated land is mainly manifested the slow decrease of forest land, grassland, and unutilized land, and the gradual growth of rural residential land. The URID index in MRA is the highest, with an average of 0.3918. MRA in the stage of high-level URID. The score gap of the county-level administrative units within the region is very large, the highest score is as high as 0.709; the scores of most county-level administrative units are between 0.3-0.5. The county-level administrative units with the highest scores are mainly the municipal districts of Jinan and Qingdao, which is the two biggest cities in Shandong Province. In MRA, fragmented functional land has been developed in succession, and rural land use transition is more reflected in structural optimization. The mode of agricultural production is more modern and rural life is more livable. URID makes substantive progress.

The URID sub dimensional indexes of MRA show that public service provision has become the key link leading URID. The effects of facility connectivity and technology 
transmission decline continuously, meaning that the corresponding enabling effect will also decrease after the construction of facilities is improved. The influence of commodity circulation determined by agricultural production has further declined. In MRA, the boundaries between urban and rural areas have become blurred in population density, industrial development, inter-personal relationships, etc., and even the differences between urban and rural areas gradually fade away. From 2014 to 2018, the URID index decreased significantly, caused by the change in environmental governance cooperation data. Since 2014, rural environmental governance has been improved. Based on the weight rule of the entropy method, the larger difference of time series values leads to the greater importance of this index, and the impact of such indicators decreases the overall growth momentum. This shows that URID in MRA places more weight on the ecological environment field.

The regression shows that rural land use transition in MRA is weakly correlated with URID, and only the coefficient of cultivated land transition is significantly positive. MRA has passed the stage of relying on 'land grabbing'. Under the influence of urban spillover effect, rural industry continues to revive, rural population flows back, and rural facilities have been continuously improved. This presents a state of deep integration between urban and rural areas.

In general, the intensity of rural land use transition of RRA, SRA, and MRA has gradually weakened, and the level of URID has also increased accordingly. This shows that, with the improvement of urbanization level, the relationship between urban and rural areas has changed from separation to integration, and from competition to complementarity. Based on the logic of URID, that cities drive rural areas, urban spillover effects such as industrial chain effect, population migration effect, and social welfare effect are the foundation stone of URID. This verifies hypothesis 'H2: The association between rural land use transition and URID presents dynamic changes.'

The above results show that rural land use transition in RRA, SRA, and MRA affects URID through urban-rural linkages. With the improvement in the stage of URID, the association between rural land use transition and URID also changes periodically.

\section{Discussion and Further Analysis}

\subsection{Association between Rural Land Use Transition and URID's Process}

According to the research results, there is a clear indication relationship between rural land use transition and URID. The transformation of various types of rural land is closely related to URID index, aided by diversified urban-rural linkages. This reflects the new path dependence of rural land use transformation in the process of URID. As Jiang et al. [48] pointed out, rural land use has been radically changed by rapid industrialization, urbanization, and agriculture modernization. With the deepening of urbanization, the traditional urban-biased land development policy is unsustainable, and the concept of "industry promotes agriculture, urban area elevates rural area" is favored. Under the influence of various urban-rural linkages, rural land presents multi-functional evolution, including not only the function of producing agricultural products, but also market returns or policy support from rural economic and cultural inheritance, environmental protection, food safety, landscape value, and animal protection. In the current stage of URID, the transformation of rural land use is no longer oriented to construction land, but shows the trend of multi-functional three-dimensional patterns and compound utilization, which provides a clue for grasping the new trend of rural land use transformation.

The research results also reveal that there is a corresponding relationship between URID and rural land use transition in different kinds of rural areas. The relationship is not a linearly increasing sequence which is related to the diversification and intensity of urban-rural linkages. For a long time, the openness of an urban and rural regional system determined that cities and villages have never been closed and independent economies. There has always been close production links and extensive social cooperation between urban and rural areas. With the improvement of URID level, the relationship between urban and rural areas has changed from separation to integration, and from competition to 
complementarity. This performance depends on the possibility of introducing and carrying urban-rural linkages in different rural areas based on rural characteristics. In order to realize industry re-feeding agriculture and cities supporting rural areas, land sharing strategies should be prioritized in urban and agricultural areas to increase landscape multi-functionality for enhancing economic growth, reducing social transaction costs, and providing ecosystem service delivery [49], which helps to promote agricultural and rural modernization, protect farmers' rights and benefits, narrow the urban-rural gap, promote cultivated land conservation and optimal allocation of land resources etc. [50-52]. This is the most realistic basis for the integrated development of urban and rural areas and is the inevitable path to realize China's rural revitalization strategy $[2,53]$.

Lastly, the association between rural land use transition and URID implies that the reconstruction of the socio-economic structure of urban-rural integration will inevitably affect the land use mode and allocation pattern of rural areas. As the cornerstone of URID, urban-rural linkages are a comprehensive embodiment of the diffusion and return effect dominated by cities and the spontaneous growth force dominated by villages [32,54]. This shows the flow of urban-rural production factors under specific geographical conditions [33,37]. Rural differences will affect the performance of urban-rural linkages and further determine the different evolution paths of rural areas. The historic division of urban and rural no longer characterizes the diversity of spaces in which food provisioning activities, urban forms, culture, and livelihoods coexist [55]; functional enhancement or addition is proposed to account for the varied evolutionary trajectories that non-metropolitan spaces are taking [56]. Based on the unified construction land market and ecological security pattern of urban and rural areas, there is a competitive and cooperative relationship between economic growth and sustainable land management in urban and rural areas, which will lead to conflicts between agriculture land and non-agricultural industries land, and between agricultural production internal land as well as agricultural production land and ecological land [57-59]. On the other hand, with the transformation of rural functions triggered by rural-urban linkages, the pattern of rural land use shows a double expansion from the periphery to the core and from 'one-way' to 'bilateral' interaction. It is necessary to improve the rural land use programmes for the coordination of rural production-livingecological space and the balanced development of urban and rural areas.

\subsection{Policy Enlightenment}

In order to further explore the driving force from the external environment for URID in RRA, SRA, and MRA and find effective policies to promote URID, the control variables are further analyzed.

GDP has a positive impact on URID in SRA. It has been proven by practice that economic growth is the key to ending the current sluggish growth predicament. As far as SRA is concerned, the higher the level of regional economic development is, the more significant the agglomeration driving effect of urban internal scale economy is, the more opportunities cities provide for rural areas, and the closer urban-rural linkages are. This means that strengthening regional economic growth is a feasible way to promote URID in SRA.

Population urbanization rate has a positive impact on URID in RRA and MRA. Following the improvement of the urbanization level, central cities and urban agglomerations have become the main space forms carrying economy and population, which form the growth poles with strong driving ability for URID. High quality of the urbanization represented by population agglomeration narrows the gap of urban and rural economic and social development, and provides more opportunities for the production factors flow and efficient allocation between urban and rural areas. Urban and rural areas have achieved consistency in development policies by adopting the idea of 'introducing urban consumption into rural areas,' which promotes rural evolution to the spatial functional structure of 'urban daily system' [7], and enables optimized URID. 
The coefficient of public budget revenue is not significant. Public budget revenue represents the government's supply of public services, and it is the representative of public policy executive power. Usually, the construction of urban service facilities supported by government finance plays a leading role in the local economy. In our study, there is insufficient evidence to support this view. This indicates that promoting URID cannot rely on the government alone. Rural pilot construction relying solely on government guidance lacks the internal driving force of sustainable development. The conclusions of this study are consistent with the findings of Zhu et al. [41], and the state-manipulated spatial dispersion may not help achieve true and real spatial equality. To some extent, it is useful for balancing the urban-rural development gap, but not promoting URID. It is necessary to build a diversified relationship between urban and rural areas with more extensive market forces. It has been proven in practice in many places, such as Walo [60], who claimed that raised improved provision of rural microfinance and access to market information would strengthen rural-urban linkages for local economic development.

Therefore, the level of economic development and urbanization are an important driving force for URID, and remain a pivotal role in different stages of URID. This also means that the relevant policies to promote URID need to consider the differences in the level of economic development and urbanization in different rural areas. Each region needs to formulate targeted strategies to promote URID in light of local conditions.

The results reveal that there are stages for rural areas to take the road of URID. Different types of rural areas can take different actions to promote URID through strengthening or introducing urban-rural linkages driven by economies of scale, urbanization, and public goods and services provision. This provides reference for promoting URID and rural revitalization through rural land use transition in the new period.

\section{Conclusions}

After entering the 21st century, the urbanization growth rate of developing countries continues to be higher than that of developed countries. A rapid urbanization process causes a series of problems, such as excessive urbanization, lagging urbanization, rural recession, and so on. To solve the development dilemma of urbanization in developing countries, it is necessary to rediscover the urbanization path with full considerations of the rational distribution and utilization of urban and rural resources. As an ideal development concept, URID is raised to explore the transformation process from the traditional urbanrural dual structure system to the urban-rural unitary structure system. Starting from different kinds of rural areas, we survey URID from the perspective of rural land use transition based on the transmission mechanism of urban-rural linkages. This provides the references for grasping the future rural regional development trend and puts forward the path to promote the integrated development of urban and rural areas.

We focused on the indicative role of rural land internal conversion on URID, creatively constructed an index system to measure the level of URID on the basis of urban-rural linkages according the association mechanism analysis between rural land use transition and URID, and empirically explored the relationship between rural land use transformation and URID by using the county-level panel data from 2009 to 2018. It was found that there is a close mutual feedback between urban and rural areas in their function, structure, and morphological evolution. The superposition effect of various urban-rural linkages interferes with rural land use transition, which is the realistic basis for the realization of URID. Meanwhile, rural land use transition is a strategic choice made by rural areas after comparing the economic and social benefits from land use, and it plays a role in URID via implanting or strengthening urban-rural linkages. The findings confirmed the well-known facts about the urban-rural relationship. It is the basis for serving the functional orientation of urban and rural areas, dealing with the dual relationship between urban and rural areas, and improving the systems, mechanisms, and institutions related to URID. 
We extend the cognition of the dynamic relationship assumption between rural land use transformation and URID stages, and give a clue for understanding the development path of urban-rural integration in different regions.

(1) Urban and rural development should not be regarded as separate processes. URID is one of the various modes in the field of dealing with urban-rural relations. The transformation of various types of rural land is closely related to URID. It provides a reference for stimulating the endogenous vitality of urban-rural areas by reorganizing the original rural spatial structure. In the context of simultaneously promoting rural revitalization and a new urbanization strategy, it is particularly important to make the rural economy flourish and speed up urbanization. Based on the logic of URID that cities drive rural areas, urban spillover effects such as industrial chain effect, population migration effect. and social welfare effect are the foundation stone of URID. This development concept is also in line with most people's expectations for future rural development.

(2) URID in rural areas is a phased and long-term development path. The exploration of URID represents a difficult transition to a new development model. Based on the dynamic characteristics of URID, rural areas are required to break the inherent development path dependence and promote the construction of the urban-rural economic community, grass-roots governance in villages and towns, and the renewal and reconstruction of traditional culture, which force the current rural land use model to make new choices. The transformation of rural land use is also the process of reorganizing the original urban-rural spatial structure, so as to provide clues for exploring the mechanism of activating rural development potential by promoting URID.

(3) Promoting URID is a systematic project which is bound up with regional development environment. Different types of rural areas can take different actions to promote URID through strengthening or introducing urban-rural linkages driven by expanding the regional economy, continuously improving the level of urbanization and strengthening the market-oriented policy design. The change in analytical thinking of urban-rural integrated development shows the evolution process of the city from a "single-center" to a "multi-center" structure. Urban spatial growth is produced by spontaneous order such as convenient transportation, agglomeration of industrial production factors, and market scale, which are the embodiment of the geographical proximity effect. However, this does not mean that the integrated development of urban and rural areas is simply to continue to promote urbanization, because the analysis ideas of "single city" or "cityhinterland" are more reminiscent of the original urban evolution process, and can not reveal the new spatial connections and evolution rules. The idea of urban-rural integration development considers the interdependence between urban and rural areas, and makes further exploration of urban-rural spatial decomposition, causal reasoning, and structural modelling.

(4) URID is the beginning of breaking the urban-rural dual system, however, it is not a replacement. URID combines the two strategies of new urbanization and rural revitalization, and explores new ways to stimulate regional development vitality, such as finding more industrial cooperation carriers, opening up factor circulation channels between urban and rural areas, sharing urban and rural public service facilities, etc. Now there is a misguided inlcination to simply equate urbanization with issues of the integration of urban and rural areas. It is not feasible to continue to repeat the original path of urbanization. Only by actively exploring a new road of urban-rural integration can we continue to promote urbanization. When the progress of social productivity bridges the gap between urban and rural areas, the urban and rural dual structure is concluded and replaced by the unitary urban-rural structure; urban-rural integration development will lose its significance because urban and rural areas are homogeneous.

From the point of view of land use policy, the restrictions on the scale limit of new construction land are becoming more and more strict. Different from the conversion of agricultural land to construction land in the past, land use transition is more reflected in the internal structural adjustment of rural land use. With the development of regional 
clusters/networks, rural areas are gradually incorporated into this system, and URID has become an inevitable trend based on the goals of complementary natural functions and common prosperity of urban and rural areas. Rural land use transition is the direct mapping of the state of URID.

In this study, the recessive morphology of rural land use transition has not been analyzed or restrained by the data. In practice, the dominant morphology of rural land use transition is easy to realize through actions such as land comprehensive improvement, however, it is difficult to quickly achieve the goals of rural land use recessive transition reflecting in the land benefits, management mode, and governance organization, which are the core goals of URID for improving urban-rural cooperation. In the future, it is necessary to analyze the association between rural land use recessive transition and URID from a micro perspective, such as villages and farmers' organizations, as well as to explore the integration process of urban and rural areas from material space to higher-level social space and provide the clues for grasping the trend of URID.

Author Contributions: Conceptualization, Z.Y.; Methodology, Z.Y.; Software, N.S.; Validation. Z.Y., B.Z. and N.S.; formal analysis, Y.Q.; investigation, Y.Q.; Writing-original draft preparation, Z.Y., B.Z.; Writing—review and editing, Z.Y., Y.Q. and B.Z.; supervision, Y.Q.; Funding acquisition, Z.Y. All authors have read and agreed to the published version of the manuscript.

Funding: This research was supported by the National Natural Science Fund Youth Project of China, grant number 41501606, Natural Science Fund General Project of Shandong, grant number ZR2020MD012, Key R \& D plan of Shandong (soft science project), grant number 2015; and Shandong Provincial Institutions of Higher Learning "Youth Innovation Team Development Plan" Project, grant number 2019RWG016.

Institutional Review Board Statement: Not applicable for studies not involving humans or animals.

Informed Consent Statement: Not applicable for studies not involving humans.

Data Availability Statement: The data presented in this study are openly available in [CNKI (https: // data.cnki.net/, accessed on 23 September 2021)], [Migrant Population Service Center, National Health Commission, P. R. China (http:/ / www.ldrk.org.cn/, accessed on 23 September 2021)] and [the Resource and Environmental Science Data Center of the Chinese Academy of Sciences (http: / / www.resdc.cn/, accessed on 23 September 2021)], reference number [2000-2020].

Acknowledgments: Special thanks to Institute for Studies in County Development of Shandong University for its support.

Conflicts of Interest: The authors declare no conflict of interest.

\section{References}

1. Young, A. Land Resources: Now and for the Future; Cambridge University Press: Cambridge, UK, 1999; pp. 101-133.

2. Liu, Y. Introduction to land use and rural sustainability in China. Land Use Policy 2018, 74, 1-4. [CrossRef]

3. Yang, Z.H.; Li, C.X.; Yang, J. Spatial and Temporal Characteristics of Rurality in Urban Suburb Town and Its Driving Factors Based on Land Use Transformation. Complexity 2020, 2020, 1-10. [CrossRef]

4. Brueckner, J.K. Urban Sprawl: Diagnosis and Remedies. Int. Reg. Sci. Rev. 2000, 23, 160-171. [CrossRef]

5. Kydd, J.; Dorward, A. Implications of market and coordination failures for rural development in least developed countries. J. Int. Dev 2004, 16, 951-970. [CrossRef]

6. Woods, M. Rural geography: Blurring boundaries and making connections. Prog. Hum. Geog. 2009, 33, 849-858. [CrossRef]

7. Torreggiani, D.; Dall'Ara, E.; Tassinari, P. The urban nature of agriculture: Bidirectional trends between city and countryside. Cities 2012, 29, 412-416. [CrossRef]

8. Long, H.; Qu, Y.; Tu, S.; Wang, J. Land use transitions under urbanization and their environmental effects in the farming areas of China: Research progress and prospect. Adv. Earth Sci. 2018, 33, 455-463.

9. Liu, Y. Research on the urban-rural integration and rural revitalization in the new era in China. Acta Geogr. Sin. 2018, 73, 637-650. (In Chinese) [CrossRef]

10. Isserman, A.M. In the national interest: Defining rural and urban correctly in research and public policy. Int. Reg. Sci. Rev. 2005, 28, 465-499. [CrossRef]

11. Irwin, E.G.; Bell, K.P.; Bockstael, N.E.; Newburn, D.A.; Partridge, M.D.; Wu, J. The economics of urban-rural space. Annu. Rev. Resour. Econ. 2009, 1, 435-459. [CrossRef] 
12. Brünjes, J.; Diez, J.R. 'Recession push'and 'prosperity pull' entrepreneurship in a rural developing context. Entrep. Region. Dev. 2013, 25, 251-271. [CrossRef]

13. Stellmes, M.; Röder, A.; Udelhoven, T.; Hill, J. Mapping syndromes of land change in Spain with remote sensing time series, demographic and climatic data. Land Use Policy 2013, 30, 685-702. [CrossRef]

14. Yang, Z.; Li, C.; Fang, Y. Driving Factors of the Industrial Land Transfer Price Based on a Geographically Weighted Regression Model: Evidence from a Rural Land System Reform Pilot in China. Land 2020, 9, 7. [CrossRef]

15. Long, H.; Wu, X.; Wang, W.; Dong, G. Analysis of urban-rural land-use change during 1995-2006 and its policy dimensional driving forces in Chongqing, China. Sensors 2008, 8, 681-699. [CrossRef] [PubMed]

16. Li, Y. Urban-rural interaction patterns and dynamic land use: Implications for urban-rural integration in China. Reg. Environ. Chang. 2012, 12, 803-812. [CrossRef]

17. Serra, P.; Vera, A.; Tulla, A.F.; Salvati, L. Beyond urban-rural dichotomy: Exploring socioeconomic and land-use processes of change in Spain (1991-2011). Appl. Geogr. 2014, 55, 71-81. [CrossRef]

18. Williams, K.; Schirmer, J. Understanding the relationship between social change and its impacts: The experience of rural land use change in south-eastern Australia. J. Rural Stud. 2012, 28, 538-548. [CrossRef]

19. Li, Y.; Chen, C.; Wang, Y.; Liu, Y. Urban-rural transformation and farmland conversion in China: The application of the environmental Kuznets Curve. J. Rural Stud. 2014, 36, 311-317. [CrossRef]

20. Zhu, F.; Zhang, F.; Ke, X. Rural industrial restructuring in China's metropolitan suburbs: Evidence from the land use transition of rural enterprises in suburban Beijing. Land Use Policy 2018, 74, 121-129. [CrossRef]

21. Kathleen, O. The influence of land use changes on open defecation in rural India. Appl. Geogr. 2018, 99, 133-139. [CrossRef]

22. Prabhakar, S. A succinct review and analysis of drivers and impacts of agricultural land transformations in Asia. Land Use Policy 2021, 102, 105238. [CrossRef]

23. Li, Y.; Li, Y.; Westlund, H.; Liu, Y. Urban-rural transformation in relation to cultivated land conversion in China: Implications for optimizing land use and balanced regional development. Land Use Policy 2015, 47, 218-224. [CrossRef]

24. Chen, K.; Long, H.; Liao, L.; Tu, S.; Li, T. Land use transitions and urban-rural integrated development: Theoretical framework and China's evidence. Land Use Policy 2020, 92, 104465. [CrossRef]

25. Wang, M.; Yang, Y.; Guo, T. Measurement of Urban-Rural Integration Level in Suburbs and Exurbs of Big Cities Based on Land-Use Change in Inland China: Chengdu. Land 2021, 10, 474. [CrossRef]

26. Ma, L.; Liu, S.; Fang, F.; Che, X.; Chen, M. Evaluation of urban-rural difference and integration based on quality of life. Sustain. Cities Soc. 2019, 54, 101877. [CrossRef]

27. Brown, D.G.; Johnson, K.M.; Loveland, T.R.; Theobald, D.M. Rural land-use trends in the conterminous United States, 1950-2000. Ecol. Appl. 2005, 15, 1851-1863. [CrossRef]

28. Bakker, M.M.; Alam, S.J.; Dijk, J.V.; Rounsevell, M. Land-use change arising from rural land exchange: An agent-based simulation model. Landscape Ecol. 2015, 30, 273-286. [CrossRef]

29. Qu, Y.; Jiang, G.; Li, Z.; Tian, Y.; Wei, S. Understanding rural land use transition and regional consolidation implications in China. Land Use Policy 2019, 82, 742-753. [CrossRef]

30. Yin, J.; Zhao, X.; Zhang, W.; Wang, P. Rural Land Use Change Driven by Informal Industrialization: Evidence from Fengzhuang Village in China. Land 2020, 9, 190. [CrossRef]

31. Zou, L.; Liu, Y.; Yang, J.; Yang, S.; Wang, Y.; Hu, X. Quantitative identification and spatial analysis of land use ecologicalproduction-living functions in rural areas on China's southeast coast. Habitat Int. 2020, 100, 102182. [CrossRef]

32. Potter, R.B.; Unwin, T. Urban-rural interaction: Physical form and political process in the Third World. Cities 1995, 12, 67-73. [CrossRef]

33. Tacoli, C. Rural-urban interactions: A guide to the literature. Environ. Urban 1998, 10, 147-166. [CrossRef]

34. Partridge, M.; Bollman, R.D.; Olfert, M.R.; Alasia, A. Riding the wave of urban growth in the countryside: Spread, backwash, or stagnation? Land Econ. 2007, 83, 128-152. [CrossRef]

35. Arnaiz-Schmitz, C.; Schmitz, M.F.; Herrero-Jáuregui, C.; Gutiérrez-Angonese, J.; Pineda, F.D.; Montes, C. Identifying socioecological networks in rural-urban gradients: Diagnosis of a changing cultural landscape. Sci. Total Environ. 2018, 612, 625-635. [CrossRef] [PubMed]

36. Ji, X.; Ren, J.; Sergio, U. Towards urban-rural sustainable cooperation: Models and policy implication. J. Clean. Prod. 2019, 213, 892-898. [CrossRef]

37. Douglass, M. A regional network strategy for reciprocal rural-urban linkages: An agenda for policy research with reference to Indonesia. Third World Plan. Rev. 1998, 20, 1. [CrossRef]

38. Lin, G.C. Metropolitan development in a transitional socialist economy: Spatial restructuring in the Pearl River Delta, China. Urban Stud. 2001, 38, 383-406. [CrossRef]

39. Rangel-Preciado, J.F.; Parejo-Moruno, F.M.; Cruz-Hidalgo, E.; Castellano-Álvarez, F.J. Rural Districts and Business Agglomerations in Low-Density Business Environments. The Case of Extremadura (Spain). Land 2021, 10, 280. [CrossRef]

40. Bittner, C.; Sofer, M. Land use changes in the rural-urban fringe: An Israeli case study. Land Use Policy 2013, 33, 11-19. [CrossRef]

41. Zhu, J.; Zhu, M.; Xiao, Y. Urbanization for rural development: Spatial paradigm shifts toward inclusive urban-rural integrated development in China. J. Rural Stud. 2019, 71, 94-103. [CrossRef]

42. Long, H. Land Use Transitions and Rural Restructuring in China; Springer: Berlin/Heidelberg, Germany, 2020 ; p. 5. 
43. Berdegué, J.A.; Carriazo, F.; Jara, B.; Modrego, F.; Soloaga, I. Cities, territories, and inclusive growth: Unraveling urban-rural linkages in Chile, Colombia, and Mexico. World Dev. 2015, 73, 56-71. [CrossRef]

44. Bosworth, G.; Venhorst, V. Economic linkages between urban and rural regions-What's in it for the rural? Reg. Stud. 2018, 52, 1075-1085. [CrossRef]

45. Veneri, P.; Ruiz, V. Urban-To-Rural Population Growth Linkages: Evidence from OECD Tl3 Regions. J. Reg. Sci. 2016, 56, 3-24. [CrossRef]

46. Olsson, J. Rural-urban spatial interaction in the global south: Long-distance mobility changes, desires and restrictions over two decades in rural philippines. Geogr. Ann. Ser. B Hum. Geogr. 2012, 94, 287-304. [CrossRef]

47. Capps, K.A.; Bentsen, C.N.; Ramírez, A. Poverty, urbanization, and environmental degradation: Urban streams in the developing world. Freshw. Sci. 2016, 35, 429-435. [CrossRef]

48. Jiang, G.; He, X.; Qu, Y.; Zhang, R.; Meng, Y. Functional evolution of rural housing land: A comparative analysis across four typical areas representing different stages of industrialization in China. Land Use Policy 2016, 57, 645-654. [CrossRef]

49. Baró, F.; Gómez-Baggethun, E.; Haase, D. Ecosystem service bundles along the urban-rural gradient: Insights for landscape planning and management. Ecosyst. Serv. 2017, 24, 147-159. [CrossRef]

50. Zhou, Y.; Guo, Y.; Liu, Y.; Wu, W.; Li, Y. Targeted poverty alleviation and land policy innovation: Some practice and policy implications from China. Land Use Policy 2018, 74, 53-65. [CrossRef]

51. Wang, S.; Tan, S.; Yang, S.; Lin, Q.; Zhang, L. Urban-biased land development policy and the urban-rural income gap: Evidence from Hubei Province, China. Land Use Policy 2019, 87, 104066. [CrossRef]

52. Zhou, Y.; Li, X.; Liu, Y. Rural land system reforms in China: History, issues, measures and prospects. Land Use Policy 2020, 91, 104330. [CrossRef]

53. Yang, Y.; Bao, W.; Wang, Y.; Liu, Y. Measurement of urban-rural integration level and its spatial differentiation in China in the new century. Habitat Int. 2021, 117, 102420. [CrossRef]

54. Henry, M.S.; Barkley, D.L.; Bao, S. The hinterland's stake in metropolitan growth: Evidence from selected southern regions. J. Reg. Sci. 1997, 37, 479-501. [CrossRef]

55. Lerner, A.M.; Eakin, H. An obsolete dichotomy? Rethinking the rural-urban interface in terms of food security and production in the global south. Geogr. J. 2011, 177, 311-320. [CrossRef] [PubMed]

56. Clare, J.A. Mitchell. Creative destruction or creative enhancement? Understanding the transformation of rural spaces. J. Rural Stud. 2013, 32, 375-387. [CrossRef]

57. Dunk, A.; Grêt-Regamey, A.; Dalang, T.; Hersperger, A.M. Defining a typology of peri-urban land-use conflicts-A case study from Switzerland. Landsc. Urban Plan 2011, 101, 149-156. [CrossRef]

58. Adam, Y.O.; Pretzsch, J.; Darr, D. Land use conflicts in central Sudan: Perception and local coping mechanisms. Land Use Policy 2015, 42, 1-6. [CrossRef]

59. Milczarek-Andrzejewska, D.; Zawalińska, K.; Czarnecki, A. Land-use conflicts and the common agricultural policy: Evidence from Poland. Land Use Policy 2018, 73, 423-433. [CrossRef]

60. Walo, M.T. Bridging the rural-urban divide for local economic development in Nekemte and its hinterlands, Oromia, Ethiopia. J. Agric. Food Syst. Community Dev. 2016, 6, 125-143. [CrossRef] 